\title{
PENGEMBANGAN MODUL ELEKTRONIK (E-MODUL) BIOKIMIA PADA MATERI METABOLISME LIPID MENGGUNAKAN FLIP PDF PROFESSIONAL
}

\author{
Rara Seruni $^{1}$, Siti Munawaroh ${ }^{1}$, Fera Kurniadewi ${ }^{1}$, Muktiningsih Nurjayadi $^{{ }^{*}}$ \\ ${ }^{1}$ Magister Pendidikan Kimia, Fakultas Matematika dan Ilmu Pengetahuan Alam, Universitas \\ Negeri Jakarta, Jl. Rawamangun Muka, RT.11/RW.14, Rawamangun, Pulo Gadung, Kota \\ Jakarta Timur, Daerah Khusus Ibukota Jakarta 13220 \\ ${ }^{*}$ Email: muktiningsih@unj.ac.id
}

\begin{abstract}
ABSTRAK
Pembelajaran abad 21 pada era revolusi industri 4.0 menuntut inovasi dan pemanfaatan teknologi secara optimal. Penelitian ini bertujuan menghasilkan modul elektronik (e-modul) biokimia pada materi metabolisme lipid menggunakan aplikasi Flip PDF Professional. Metode yang digunakan adalah penelitian dan pengembangan model Borg dan Gall, instrumen penelitian berupa angket. Modul elektronik yang dibuat terdiri dari pendahuluan, pembahasan materi (katabolisme lipid, anabolisme lipid, kolesterol, serta penyakit terkait metabolisme lipid), video, gambar serta tes formatif pada tiap materi yang sesuai dengan capaian pembelajaran mata kuliah biokimia pada materi metabolisme lipid. Modul elektronik sudah divalidasi oleh ahli materi, bahasa, dan media; dilakukan uji coba lapangan dalam skala kecil terhadap 20 mahasiswa dan dosen biokimia. Hasil penelitian menunjukkan e-modul yang dibuat memiliki interpretasi baik dari ahli materi, bahasa, dan media dengan persentase $83,35 \%$ hingga $85,00 \%$. Hasil uji coba lapangan juga menunjukkan modul tersebut mendapatkan interpretasi yang baik dengan persentase $84,39 \%$. Melalui hasil uji coba dapat disimpulkan bahwa modul elektronik memiliki kategori baik serta mendapat respon positif mahasiswa dan dosen. Diseminasi modul elektronik pada proses pembelajaran biokimia sedang dilaksanakan dan akan dipublikasikan pada artikel selanjutnya.
\end{abstract}

Kata kunci: modul elektronik, biokimia, metabolisme lipid, flip PDF professional

\section{ABSTRACT}

$27^{\text {st }}$ century learning in the industrial revolution era 4.0 demands innovation and optimally utilizes technology. This study aims to produce biochemical electronic modules (e-module) in lipid metabolic material using the Flip PDF Professional application. The method used is the research and development of the Borg and Gall model, the research instrument in the form of a questionnaire. The produced e-module consisted of preliminaries, discussion of material (lipid catabolism, lipid anabolism, cholesterol, and lipid metabolism-related diseases), videos, images and formative tests on each material in accordance with the achievement of biochemical subject learning in lipid metabolic material. The electronic module has been validated by material, language, and media experts; a small-scale field trial was conducted on 20 biochemistry students and lecturers. The results showed that the produced e-module had good interpretations from material, language, and media experts with a percentage of $83.35 \%$ to $85.00 \%$. The results of field trials also showed that the module received a good 
interpretation with a percentage of $84.39 \%$. Through the results of the trial it can be concluded that the electronic module has a good category and gets a positive response from students and lecturers. Dissemination of electronic modules in the biochemical learning process is being carried out and will be published in the next article.

\section{Keywords: electronic module, biochemistry, lipid metabolism, flip PDF professional}

\section{DOI: http://dx.doi.org/10.15575/jtk.v4i1.4672}

\section{PENDAHULUAN}

Biokimia memiliki materi yang luas, meliputi siklus metabolisme yang memiliki jalur dan struktur kimia yang kompleks (Mutlu, 2018). Konsep lipid adalah topik penting dalam mata kuliah biokimia yang tidak mudah bagi mahasiswa untuk dikuasai (Horn \& Hernick, 2015). Untuk dapat menguasai materi metabolisme lipid, mahasiswa harus lebih sering membaca literatur, karena pembelajaran kimia mengembangkan literasi mahasiswa (Irmita \& Atun, 2017). Sedangkan hasil analisis pendahuluan menunjukkan 66,7\% mahasiswa berpendapat bahwa buku pegangan biokimia jarang mereka baca; $81,5 \%$ berpendapat buku paket biokimia yang mereka miliki kurang menarik untuk dibaca; 95,7\% berpendapat diperlukan sumber belajar yang lebih menarik dan inovatif sesuai dengan pembelajaran abad 21 serta revolusi industri 4.0.

Pembelajaran Abad 21 mengintegrasikan kemampuan literasi dengan penguasaan terhadap teknologi (Dit. PSMA Ditjen Pendidikan Dasar dan Menengah, 2017). Revolusi industri 4.0 merupakan saat teknologi menjadi dasar dalam kehidupan manusia (Aprillinda, 2019). Pembelajaran abad 21 pada revolusi industri 4.0 menuntut inovasi dan memanfaatkan teknologi secara optimal. Teknologi bukan hal asing pada revolusi industri 4.0, masyarakat menggeser aktivitas-aktivitas yang awalnya di dunia nyata, ke dunia maya (era disrupsi teknologi) (Mardhiyana \& Nasution, 2019). Pendidik pada abad 21 harus dapat memfasilitasi mahasiswa dengan berbagai inovasi teknologi seperti komputer, papan tulis elektronik, modul elektronik, dll (Larson \& Miller, 2012). Mahasiswa memerlukan sumber belajar inovatif yang dapat digunakan dimana saja dan kapan saja (Zhang et al., 2017).

Sumber belajar digunakan untuk membantu dosen dalam melaksanakan perkuliahan (Ali \& Adawiah, 2018). Sumber belajar yang mendukung pembelajaran berbasis TIK meliputi: audio, booklet, brosur, e-book, flipchart, games, jurnal, leaflet, multi media interaction (MMI), mock-up, modul elektronik, power point (PPt), video, dan web based learning (WBL) (Rahmadi dkk., 2018). Modul pembelajaran sangat membantu dalam proses pembelajaran untuk membangkitkan keinginan dan menghasilkan motivasi bagi siswa (Ferdianto \& Nurulfatwa, 2019). Kecepatan dan kemudahan dalam menyajikan informasi sebagai sumber belajar diperoleh dengan mudah jika pembelajaran menggunakan media elektronik (Triyono, 2015). Modul pembelajaran di era revolusi industri 4.0 ini bukan lagi berupa modul cetak. Saat ini banyak dikembangkan modul elektronik atau biasa dikenal dengan $e$ modul.

Modul elektronik merupakan bentuk bahan belajar mandiri yang disusun secara 
R. Seruni, S. Munawaroh, F. Kurniadewi \& M. Murjayad

sistematis yang ditampilkan dalam format elektronik, di dalamnya terdapat audio, animasi, dan navigasi (Sugianto dkk., 2013). Aplikasi yang dapat digunakan untuk membuat e-modul, diantaranya Exelearning (Pilt et al.., 2014); Kvisoft Flipbook Marker (Sugianto dkk., 2013); 3D Page Flip Professional (Ferdianto \& Nurulfatwa, 2019); dan Flip PDF Professional. Diantara aplikasi pembuat $e$-modul tersebut, aplikasi Flip PDF Professional memiliki lebih banyak kelebihan, yaitu mudah untuk digunakan karena dapat dioperasikan bagi pemula yang tidak mengetahui bahasa pemrograman HTML. Flip PDF Professional adalah pembuat flipbook kaya fitur yang memiliki fungsi edit halaman. Aplikasi ini dapat membuat halaman buku yang interaktif dengan memasukkan multimedia seperti gambar, video dari YouTube, MP4, audio video, hyperlink, kuis, flash, dan lain-lain (Professional et al., 2019).

Beberapa penelitian sebelumnya sudah mengembangkan modul elektronik sebagai sumber belajar (Pilt et al., 2014; Sugianto dkk., 2013; Ferdianto \& Nurulfatwa, 2019). Namun belum dikembangkan modul elektronik menggunakan aplikasi Flip PDF Professional yang memiliki kelebihan dan kemudahan lebih banyak dibanding software lainnya. Oleh karena itu, perlu dikembangkan bahan ajar yang tepat dengan pembelajaran abad 21 dan revolusi industri 4.0 yaitu e-modul (modul elektronik) biokimia pada materi metabolisme lipid untuk mahasiswa menggunakan aplikasi Flip PDF Professional.

\section{METODE PENELITIAN}

Metode yang digunakan adalah penelitian dan pengembangan (Research \& Development) produk pendidikan Gall et al. (2007). Penelitian yang dilakukan bertujuan untuk menghasilkan modul elektronik biokimia untuk materi metabolisme lipid.
Pengembangan Modul Elektronik (E-Modul) Biokimia pada Materi Metabolisme Lipid menggunakan Flip PDF Professional

Subjek penelitian ini adalah mahasiswa Program Studi Kimia, Fakultas Matematika dan Ilmu Pengetahuan Alam UNJ pada September 2018 - April 2019. Prosedur yang dilakukan adalah sebagai berikut.

\subsection{Studi pendahuluan}

Identifikasi kebutuhan yang melibatkan mahasiswa dan dosen kimia FMIPA UNJ untuk mendapatkan informasi kebutuhan terkait $e$-modul yang akan dikembangkan.

\subsection{Perencanaan penelitian}

Penelitian dilaksanakan di UNJ dengan waktu pengembangan e-modul pada bulan Desember 2018 - Februari 2019 dan uji coba dilakukan pada bulan Maret 2019.

\subsection{Pengembangan produk awal}

Membuat desain e-modul pada aplikasi Microsoft Publisher untuk kemudian disimpan dalam format .pdf. Modul dalam format .pdf tersebut kemudian dimasukkan ke dalam aplikasi Flip PDF Professional menjadi hasil akhir e-modul dalam bentuk flip page. Media tambahan untuk melengkapi modul, seperti audio, video, link web dan soal formatif dimasukkan menggunakan aplikasi tersebut. Materi yang dibuat sesuai dengan RPS (Rancangan Pembelajaran Semester) mata kuliah biokimia semester genap untuk materi metabolisme lipid. Materi metabolisme lipid diambil dari beberapa buku biokimia dan kimia organik, diantaranya Nelson et al. (2008), Koolman et al. (2005), dan Moffatt, R. J., \& Stamford (2005). Setelah disusun, emodul diuji kelayakannya untuk mendapatkan tanggapan dan saran dari ahli materi, media, dan bahasa.

\subsection{Uji lapangan skala kecil}

Produk awal diperbaiki sesuai dengan tanggapan dan saran ahli materi, media, dan bahasa, kemudian dilakukan uji skala kecil 
R. Seruni, S. Munawaroh, F. Kurniadewi \& M. Murjayad

pada mahasiswa dan dosen untuk mendapatkan penilaian atas produk e-modul.

\subsection{Revisi hasil uji lapangan skala kecil}

Revisi produk sesuai dengan saran dan kritik yang diperoleh dari uji lapangan skala kecil.

\subsection{Uji lapangan skala besar}

E-modul hasil revisi hasil uji lapangan terbatas kemudian diuji kembali dengan jumlah mahasiswa dan dosen yang lebih banyak.

\subsection{Revisi hasil uji lapangan skala besar}

Revisi produk sesuai dengan saran dan kritik yang diperoleh dari uji lapangan skala besar. Perbaikan operasional menghasilkan e-modul biokimia untuk materi metabolisme lipid menggunakan aplikasi Flip PDF Professional.

Instrumen yang digunakan yaitu angket analisis pendahuluan untuk mahasiswa dan dosen; angket uji ahli materi, bahasa, dan media; dan angket uji coba lapangan. Data yang diperoleh dari hasil instrumen pengkaji materi, pengkaji media, pengkaji bahasa dianalisis secara deskriptif dengan melakukan perhitungan menggunakan rating scale. Batas baik buruknya produk e-module yang didasarkan pada kriteria interpretasi skor untuk rating scale dengan rentang $0-100 \%$.

\section{HASIL DAN PEMBAHASAN}

Hasil penelitian ini adalah menghasilkan $e-$ modul biokimia untuk materi metabolisme lipid menggunakan aplikasi Flip PDF Professional ditinjau dari ahli materi, bahasa, dan media serta uji coba lapangan.

E-modul dikembangkan sebagai panduan dan sumber belajar mandiri mahasiswa (Ali \& Adawiah, 2018). Produk awal e-modul
Pengembangan Modul Elektronik (E-Modul) Biokimia pada Materi Metabolisme Lipid menggunakan Flip PDF Professional

divalidasi oleh ahli materi, bahasa dan media. Berdasarkan Tabel 1, hasil validasi ahli media, didapatkan nilai sebesar 83,35\% dengan interpretasi baik dan dilakukan beberapa revisi setelah diuji oleh ahli media. Salah satu ahli media memberikan saran agar e-modul yang dibuat menggunakan bahasa yang komunikatif agar dapat meningkatkan kegiatan interaktif dosen dan mahasiswa (Triyono, 2015). Selain itu, desain pada emodul disarankan untuk direvisi dengan lebih banyak video dan gambar agar lebih menarik dan tidak membosankan. Hasil revisi desain e-modul dapat dilihat pada gambar 1-6. Tabel 2 menunjukkan hasil perhitungan validasi ahli materi dan bahasa, diperoleh nilai sebesar $85,00 \%$ dan mendapat interpretasi baik dan terdapat revisi kecil terkait kesalahan penulisan.

Setelah dilakukan revisi $e$-modul sesuai saran ahli media, materi dan bahasa, dilakukan uji coba lapangan menggunakan angket respon mahasiswa. Dapat dilihat hasil uji coba lapangan dengan angket respon mahasiswa terhadap e-modul pada Tabel 3 diperoleh rata-rata sebesar $84,39 \%$ dengan kategori baik. Hasil analisis tersebut menunjukkan bahwa e-modul untuk mata kuliah biokimia pada materi metabolisme lipid sudah dapat digunakan untuk pembelajaran di kelas.

Penelitian sebelumnya terkait modul elektronik dalam pembelajaran memiliki tahapan yang cukup banyak (Sugianto dkk., 2013) sedangkan pada pembuatan modul elektronik dengan menggunakan aplikasi Flip PDF Professional memerlukan tahapan yang lebih ringkas. 
Tabel 1. Hasil perhitungan validasi ahli media

\begin{tabular}{|c|c|c|c|c|c|c|c|c|c|c|c|c|}
\hline \multirow{2}{*}{ No } & \multirow{2}{*}{ Indikator } & \multirow{2}{*}{ Nomor Soal } & \multirow{2}{*}{$\sum \operatorname{Max}$} & \multicolumn{3}{|c|}{ Ahli 1} & \multicolumn{3}{|c|}{ Ahli 2} & \multicolumn{3}{|c|}{ Ahli 3} \\
\hline & & & & $\Sigma$ & $\%$ & Interpretasi & $\Sigma$ & $\%$ & Interpretasi & $\Sigma$ & $\%$ & Interpretasi \\
\hline \multicolumn{13}{|c|}{ Cover e-modul } \\
\hline \multirow[t]{2}{*}{1} & Tata Letak Cover e-modul & & & & & & & & & & & \\
\hline & A. Design Cover e-modul & $1,2,3,4,5,6,7,8$ & 80 & 63 & 78,75 & Baik & 67 & 83,75 & Baik & 68 & 85,00 & Baik \\
\hline \multirow[t]{3}{*}{2} & Tipografi Cover e-modul & & & & & & & & & & & \\
\hline & $\begin{array}{l}\text { A. Huruf yang digunakan menarik } \\
\text { dan mudah dibaca }\end{array}$ & $9,10,11$ & 30 & 25 & 83,33 & Baik & 26 & 86,67 & Baik & 24 & 80,00 & Baik \\
\hline & B. Huruf yang sederhana & $12,13,14$ & 30 & 25 & 83,33 & Baik & 26 & 86,67 & Baik & 24 & 80,00 & Baik \\
\hline \multirow[t]{2}{*}{3} & |llustrasi Cover e-modul & & & & & & & & & & & \\
\hline & A. Isi Cover e-modul & $15,16,17$ & 30 & 24 & 80,00 & Baik & 25 & 83,33 & Baik & 25 & 83,33 & Baik \\
\hline \multicolumn{13}{|c|}{ Design Isi $e$-Modul } \\
\hline \multirow{5}{*}{4} & Tata Letak Isi e-modul & & & & & & & & & & & \\
\hline & A. Tata letak konsisten & $18,19,20,21$ & 40 & 32 & 80,00 & Baik & 33 & 82,50 & Baik & 35 & 87,50 & Baik \\
\hline & B. Unsur tata letak harmonis & $22,23,24,25$ & 40 & 33 & 82,50 & Baik & 34 & 85,00 & Baik & 34 & 85,00 & Baik \\
\hline & $\begin{array}{l}\text { C. Penempatan dan penampilan } \\
\text { unsur tata letak }\end{array}$ & $\begin{array}{c}26,27,28,29,30 \\
31\end{array}$ & 60 & 50 & 83,33 & Baik & 51 & 85,00 & Baik & 51 & 85,00 & Baik \\
\hline & $\begin{array}{l}\text { D. Tata letak mempercepat } \\
\text { pemahaman }\end{array}$ & 32,33 & 20 & 16 & 80,00 & Baik & 18 & 90,00 & Baik & 16 & 80,00 & Baik \\
\hline \multirow{7}{*}{5} & Tipografi Isi e-modul & & & & & & & & & & & \\
\hline & A. Tipografi sederhana & $34,35,36$ & 30 & 26 & 86,67 & Baik & 25 & 83,33 & Baik & 26 & 86,67 & Baik \\
\hline & B. Tipografi mudah dibaca & $37,38,39,40,41$ & 50 & 40 & 80,00 & Baik & 43 & 86,00 & Baik & 38 & 76,00 & Baik \\
\hline & $\begin{array}{l}\text { C. Tipografi memudahkan } \\
\text { pemahaman }\end{array}$ & $42,43,44,45$ & 40 & 31 & 77,50 & Baik & 34 & 85,00 & Baik & 34 & 85,00 & Baik \\
\hline & Ilustrasi Isi $e$-modul & & & & & & & & & & & \\
\hline & $\begin{array}{l}\text { A. Ilustrasi memperjelas dan } \\
\text { mempermudah pemahaman }\end{array}$ & $46,47,48$ & 30 & 23 & 76,67 & Baik & 25 & 83,33 & Baik & 26 & 86,67 & Baik \\
\hline & $\begin{array}{l}\text { B. llustrasi isi menimbulkan daya } \\
\text { tarik }\end{array}$ & $49,50,51,52,53$ & 50 & 43 & 86,00 & Baik & 42 & 84,00 & Baik & 44 & 88,00 & Baik \\
\hline
\end{tabular}

Tabel 2. Hasil perhitungan validasi ahli materi dan bahasa

\begin{tabular}{|c|c|c|c|c|c|c|c|c|c|c|c|c|}
\hline \multirow{2}{*}{ No } & \multirow{2}{*}{ Indikator } & \multirow{2}{*}{ Nomor Soal } & \multirow{2}{*}{$\sum \operatorname{Max}$} & \multicolumn{3}{|c|}{ Ahli 1} & \multicolumn{3}{|c|}{ Ahli 2} & \multicolumn{3}{|c|}{ Ahli 3} \\
\hline & & & & $\Sigma$ & $\%$ & Interpretasi & $\Sigma$ & $\%$ & Interpretasi & $\Sigma$ & $\%$ & Interpretasi \\
\hline \multicolumn{13}{|c|}{ Isi } \\
\hline 1 & Cakupan Materi & $1,2,3$ & 30 & 27 & 90,00 & Baik & 27 & 90,00 & Baik & 24 & 80,00 & Baik \\
\hline 2 & Keakuratan Materi & 4,5 & 20 & 18 & 90,00 & Baik & 17 & 85,00 & Baik & 18 & 90,00 & Baik \\
\hline 3 & \begin{tabular}{|l|l} 
Keterampilan \\
\end{tabular} & 6,7 & 20 & 18 & 90,00 & Baik & 16 & 80,00 & Baik & 16 & 80,00 & Baik \\
\hline \multicolumn{13}{|c|}{ Kebahasaan } \\
\hline 4 & $\begin{array}{l}\text { Sesuai dengan perkembangan } \\
\text { peserta didik }\end{array}$ & 8,9 & 20 & 18 & 90,00 & Baik & 18 & 90,00 & Baik & 16 & 80,00 & Baik \\
\hline 5 & Komunikatif & 10,11 & 20 & 18 & 90,00 & Baik & 16 & 80,00 & Baik & 15 & 75,00 & Baik \\
\hline 6 & Kemampuan memotivasi & 12,13 & 20 & 18 & 90,00 & Baik & 17 & 85,00 & Baik & 17 & 85,00 & Baik \\
\hline 7 & Kelugasan & 14,15 & 20 & 18 & 90,00 & Baik & 17 & 85,00 & Baik & 16 & 80,00 & Baik \\
\hline 8 & Koherensi dan keruntutan alur pil & 16 & 10 & 8 & 80,00 & Baik & 9 & 90,00 & Baik & 8 & 80,00 & Baik \\
\hline 9 & Kesesuaian dengan kaidah bahasa & 17,18 & 20 & 18 & 90,00 & Baik & 16 & 80,00 & Baik & 16 & 80,00 & Baik \\
\hline 10 & $\begin{array}{l}\text { Penggunaan istilah dan } \\
\text { simbol/lambang kimia }\end{array}$ & 19,20 & 20 & 18 & 90,00 & Baik & 17 & 85,00 & Baik & 16 & 80,00 & Baik \\
\hline
\end{tabular}

Tabel 3. Hasil uji lapangan e-modul

\begin{tabular}{|c|l|c|c|c|c|c|}
\hline No & Indikator & Nomor Soal & Skor Max & Skor & $\%$ & Interpretasi \\
\hline \hline 1 & Kesesuaian materi $E$-modul dengan & $1,2,10$ & 600 & 525 & 87,50 & Baik \\
2 & Kejelasan isi $E$-modul & $3,8,9,12,13$ & 1000 & 832 & 83,20 & Baik \\
3 & Fungsi soal sebagai alat evaluasi & 11 & 200 & 165 & 82,50 & Baik \\
4 & Bahasa & 5,6 & 400 & 339 & 84,75 & Baik \\
\hline 5 & Design tampilan & $4,7,14,15,16$ & 1000 & 840 & 84,00 & Baik \\
\hline
\end{tabular}


R. Seruni, S. Munawaroh, F. Kurniadewi \& M. Murjayad

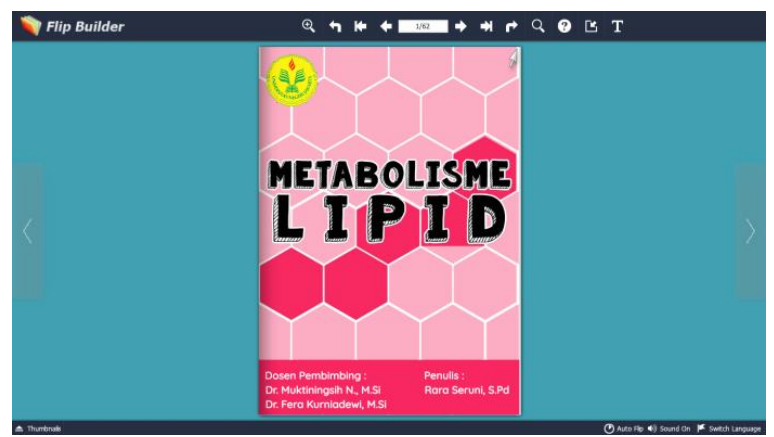

Gambar 1. Desain awal cover e-modul

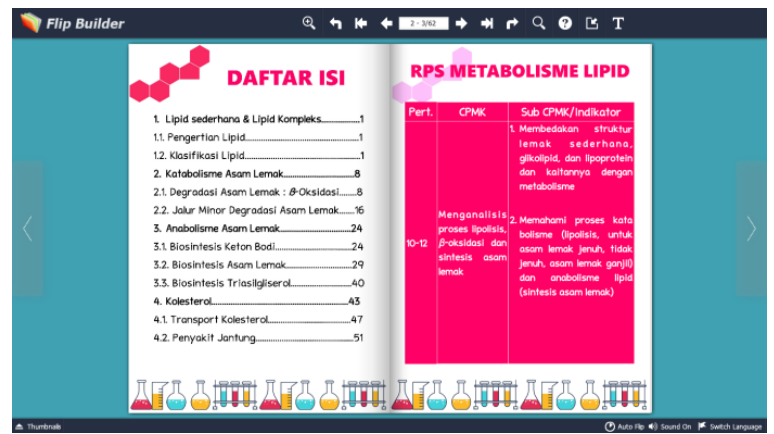

Gambar 2. Desain awal pendahuluan e-modul

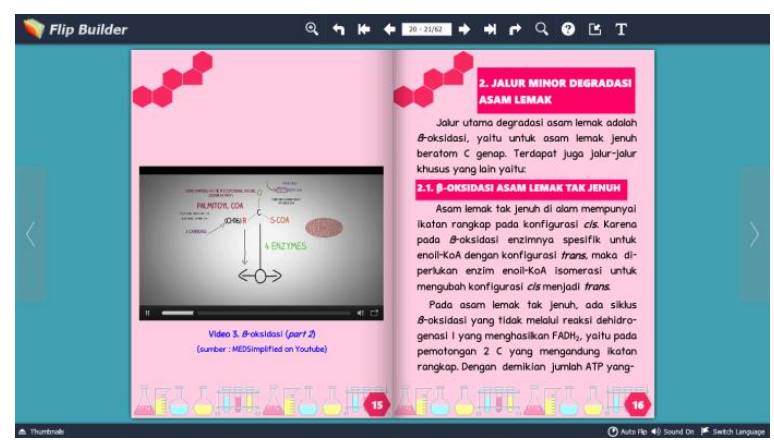

Gambar 3. Desain awal isi dari e-modul

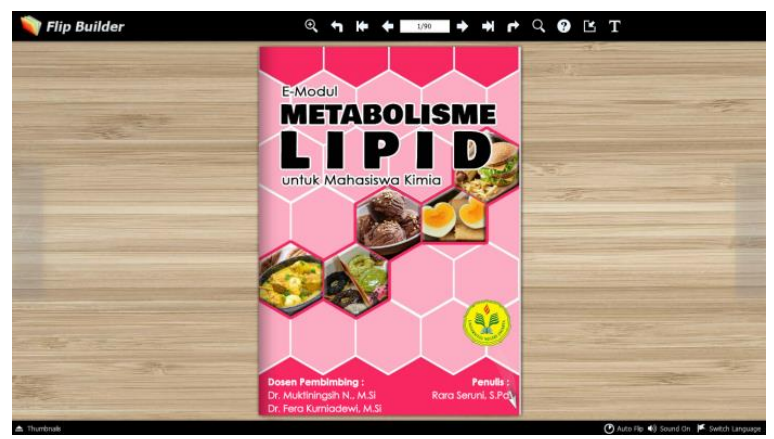

Gambar 4. Desain akhir cover e-modul
Pengembangan Modul Elektronik (E-Modul) Biokimia pada Materi Metabolisme Lipid menggunakan Flip PDF Professional

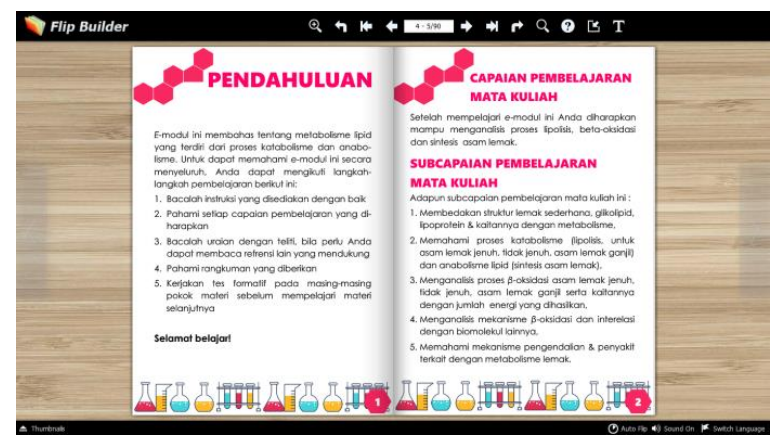

Gambar 5. Desain akhir pendahuluan e-modul

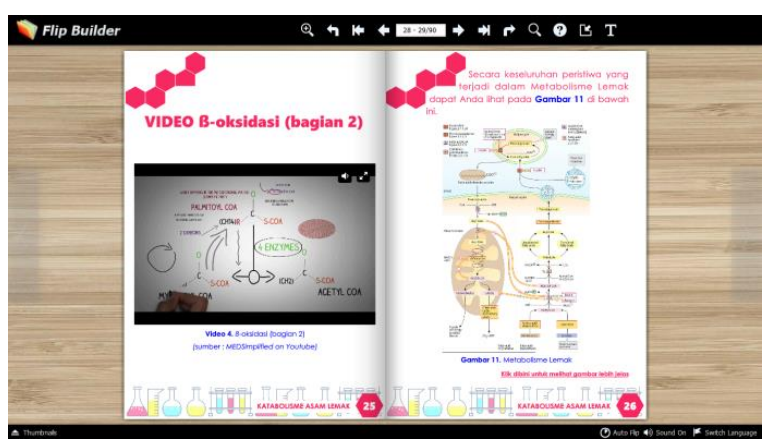

Gambar 6. Desain akhir isi dari e-modul

Selain itu, media yang dianggap efektif dan efisien untuk digunakan belajar mandiri adalah modul elektronik. Ini sesuai dengan penelitian yang telah dilakukan sebelumnya oleh Ferdianto dkk. (2019) berjudul "3D Page Flip Professional: Enhance of Representation Mathematical Ability on Linear Equation in One Variable." Pembelajaran pun akan lebih bermakna jika menggunakan modul elektronik, ini juga sesuai dengan penelitian yang dilakukan oleh Pilt et al. (2007) berjudul "Tool for creating learning modules developed on the basis of open source OpenScholar software".

Aplikasi Flip PDF Professional yang kami gunakan memungkinkan untuk mengakses $e$ modul di smartphone tetapi untuk media yang kami buat belum kami kembangkan untuk dapat diakses di smartphone. Penelitian berikutnya mungkin dapat membuat $e$-modul dengan aplikasi ini yang dapat diakses di smartphone sehingga memudahkan mahasiswa mempelajari isi e-modul tanpa harus membuka laptop. Selain itu, pengujian 
R. Seruni, S. Munawaroh, F. Kurniadewi \& M. Murjayad

efektifitas dari $e$-modul yang kami buat untuk meningkatkan kemampuan berpikir kritis sedang dilaksanakan dan akan dipublikasikan pada artikel selanjutnya.

\section{KESIMPULAN}

Hasil penelitian menunjukkan e-modul yang dikembangkan memperoleh persentase ratarata ahli materi dan bahasa $85,00 \%$ dan ahli media $83,35 \%$. Persentase rata-rata respon mahasiswa pada uji lapangan yaitu $84,39 \%$ pada interpretasi baik dan layak, dari hasil tersebut disimpulkan bahwa produk pengembangan yaitu e-modul metabolisme lipid layak digunakan untuk proses pembelajaran.
Pengembangan Modul Elektronik (E-Modul) Biokimia pada Materi Metabolisme Lipid menggunakan Flip PDF Professional 
R. Seruni, S. Munawaroh, F. Kurniadewi \& M. Murjayad

\section{DAFTAR PUSTAKA}

Ali, M., \& Adawiah, R. (2018). Pengembangan Bahan Ajar Berbasis Video Pembelajaran Pada Mata Kuliah Pemecahan Masalah. Prosiding National Conference Mathematics, Science, Adn Education, (September), 287-294.

Aprillinda, M. (2019). Perkembangan Guru Profesional Di Era Revolusi Industri 4 . 0. In Prosiding Seminar Nasional Pendidikan Program Pascasarjana.

Dit. PSMA Ditjen Pendidikan Dasar dan Menengah. (2017). Panduan Implementasi Kecakapan Abad 21 Kurikulum 2013. Jakarta: Kementerian Pendidikan dan Kebudayaan.

Ferdianto, F., \& Nurulfatwa, D. (2019). 3D Page Flip Professional: Enhance of Representation Mathematical Ability on Linear Equation in One Variable. Journal of Physics: Conference Series, 1188(1), 012043.

Gall, M. D., Borg, W. R., \& Gall, J. P. (2007). Educational Research: An Introduction, 8th Edition. Longman Publishing.

Horn, S., \& Hernick, M. (2015). Improving Student Understanding of Lipids Concepts in a Biochemistry Course Using Test-Enhanced Learning. Chemistry Education Research and Practice, 16(4).

Irmita, L. U., \& Atun, S. (2017). Pengembangan Perangkat Pembelajaran Menggunakan Pendekatan Tpak untuk Meningkatkan Literasi Sains. Jurnal Tadris Kimiya, 2(1), 84-90.

Koolman, J., Röhm, K. H., Wirth, J., \& Robertson, M. (2005). Color Atlas of
Pengembangan Modul Elektronik (E-Modul) Biokimia pada Materi Metabolisme Lipid menggunakan Flip PDF Professional

Biochemistry (Vol 2). Stuttgart: Thieme.

Larson, L. C., \& Miller, T. N. (2012). 21st Century Skills: Prepare Students for the Future. Kappa Delta Pi Record, 47(3), 121-123.

Mardhiyana, D., \& Nasution, N. B. (2019). Kesiapan Mahasiswa Pendidikan Matematika Menggunakan E-Learning dalam Menghadapi Era Revolusi Industri 4.0. Seminar Nasional Pendidikan Matematika Ahmad Dahlan 2018, 6.

Moffatt, R. J., \& Stamford, B. (2005). Lipid Metabolism and Health. CRC Press.

Mutlu, A. (2018). Comparison of Two Different Techniques of Cooperative Learning Approach: Undergraduates' Conceptual Understanding in The Context of Hormone Biochemistry. Biochemistry and Molecular Biology Education, 46(2), 114120.

Nelson, D. L., Lehninger, A. L., \& Cox, M. M. (2008). Lehninger Principles of Biochemistry (Fourt Edition). Macmillan.

Pilt, L., Tartes, T., \& Morandi, T. (2014). Tool for Creating Learning Modules Developed on The Basis of Open Source OpenScholar Software. EUNIS Journal of Higher Education.

Professional, F. P. D. F., Flip, W., Professional, P. D. F., Windows, F., Service, O., \& Upgrade, P. (2019). Flip PDF Professional Interactive publishing - add video, image, link and.

Rahmadi, I. F., Khaerudin, \& Kustandi, C. (2018). Kebutuhan Sumber Belajar Mahasiswa yang Mendukung Pembelajaran Berbasis Teknologi 
R. Seruni, S. Munawaroh, F. Kurniadewi \& M. Murjayad

Informasi dan Komunikasi di Perguruan Tinggi. Jurnal Teknologi Pendidikan, 20(2)

Sugianto, D., Abdullah, A. G., Elvyanti, S., \& Muladi, Y. (2013). Modul Virtual: Multimedia Flipbook Dasar Teknik Digital. Innovation of Vocational Technology Education, 9(2), 101-116.

Triyono, M. B. (2015). The Indicators of Instructional Design for E- learning in Indonesian Vocational High Schools. In Procedia - Social and Behavioral Sciences (Vol. 204, pp. 54-61). Elsevier B.V.

Zhang, J., Cai, Z., Zhao, Z., \& Ji, K. (2017). Cell Phone-based Online Biochemistry and Molecular Biology Medical Education Curriculum. Medical Education Online, 22(1).
Pengembangan Modul Elektronik (E-Modul) Biokimia pada Materi Metabolisme Lipid menggunakan Flip PDF Professional 